\title{
A Study of Ethno-Veterinary Medicinal Plants and In Vitro Antimicrobial Activities Against Bovine Mastitis Isolated Bacterial Pathogens in Algeria
}

\author{
Radhwane SAIDI ${ }^{1 *}$, Nora MIMOUNE ${ }^{2,3}$, Ratiba BAAZIZI ${ }^{2}$, Mohamed Hocine BENAISSA ${ }^{4}$, Djamel \\ KHELEF $^{2}$, Rachid KAIDI ${ }^{3}$ \\ ${ }^{1}$ Department of Agronomy, Telidji Amar University, BP 37G, Ghardaïa Road, 03000 Laghouat, Algeria. \\ ${ }^{2}$ National High School of Veterinary Medicine, Bab Ezzouar, Algiers, Algeria. \\ ${ }^{3}$ Institute of Veterinary Sciences, Laboratory of biotechnology related to animal breeding, University Saad \\ Dahleb, BP: 270, Soumaa road, Blida 01, Algeria. \\ ${ }^{4}$ Scientific and Technical Research Center for Arid Areas, Biophysical Station, Touggourt, Algeria \\ *corresponding author: nora.mimoune@gmail.com
}

Bulletin UASVM Veterinary Medicine 76(2)/2019

Print ISSN 1843-5270; Electronic ISSN 1843-5378

doi:10.15835/buasvmcn-vm:2019.0010

\begin{abstract}
Bovine mastitis is the most serious dairy problem in terms of economic losses to the dairy industry. In Algeria, dominates as one of the most prevalent diseases in dairy cattle among the dairy farms. Mastitis treatment with antibiotics leads to the development of antibiotic resistant strains and consumer health problem. Multidrugresistant bacteria have become a major health issue. With new generations of virulence and resistant bacteria, we need to improve our understanding and produce novel techniques to control these pathogenic strains. In our study, the activity of several extracts from seven medicinal plants, namely Mentha pulegium, Lavandula dentate, Origanium sp, Marrubium vulgare, Salvia bicolor, Blackstonia perfoliata, and Phlomis crinita, traditionally used in Algeria was investigated against 26 methicillin resistant staphylococci and multi-resistant Escherichia coli. (E.coli) isolated from animals with mastitis manifestation by the disc diffusion method.

Results revealed the potential of extracts of Salvia bicolor, Marrubium vulgare and Phlomiscrinita as antibacterial agents against strains isolated from bovine mastitis and support the possible use of these phytotherapic agents in the clinical management of the disease. Further studies into their toxicity and phytochemistry are advocated.
\end{abstract}

Keywords: Antimicrobial activity, bovine mastitis, folk medicine, medicinal plants.

\section{Introduction}

Antibiotic-resistant bacteria cause about $90 \%$ of deaths due to infection worldwide (AlJudaibi, 2014). Multidrug-resistant bacteria have become a major health concern (Sivananthan, 2013). As alternative treatment to health problems, medicinal plants have been used for ages in developing countries. After that, its use is widespread throughout the world (Principe, 1989). Algeria has a diverse flora and a rich tradition in the use of medicinal plants for antimicrobial applications, but half of the flora in
Algeria is rare (Zeraïa, 1983). Many plant extracts have been shown to exert biological activity in vitro and in vivo, justifying research on traditional medicine focused on the characterization of antimicrobial activity of these plants (Tamert, 2012). The importance of using medicinal plants can be attributed to affordability as well as the trust in herbal medicine as an outcome from the witnessed positive results when applying herbs. Many medicinal plants are also used to treat cows, sheep, poultry, horses and pigs in Algeria (Tamert, 2012). 
Ain Defla is a small town located in the Mitidja region, Algeria, where dairy activities play an important role in the livelihood of the community from rural area. In this area, mastitis is also the most prevalent dairy health problem (Saidi et al., 2013). Staphylococcus aureus is the main causative agent of bovine mastitis followed by coagulase negative staphylococci (CNS), Streptococcus agalactiae and environmental streptococci as E.coli (Hebert et al., 2000; Bradley et al, 2004; Saidi et al., 2013).

Conventional therapeutics is usually based in antibiotics that are not always effective as bacteria become resistant. Besides, its residues in milk and meat of treated animals can affect human health and interfere in fermentation processes in the milk industry. This motivated the search for new antimicrobial agents and the study of natural plant products as substitutes for chemical antimicrobial agents in the treatment of this disease (Pandian et al., 2006). Following a survey, medicinal plants were reported by local farmers to be used for increased production of milk and for treatment of bovine mastitis and other diseases. This work is a step towards exploring the potential use of these medicinal plants indicated. Likewise, other plants traditionally used for treatment of diseases and antimicrobial application for infectious diseases were also screened against strains of Staphylococci and enterobacteria isolated from bovine mastitis to evaluated their possible use in the clinical management of the disease as phytotherapic agent.

\section{Materials and methods}

\section{Bacterial strains}

Bacterial strains used in this study were isolated from clinical cases of Bovine mastitis, namely coagulase positive staphylococci (CPS), coagulase positive staphylococci (SCN) and Escherichia coli. All the strains were confirmed by cultural and biochemical studies and maintained in nutrient agar slants at $4^{\circ} \mathrm{C}$ for further use (antibiogram). Only, clinical isolates identified as multiple-drug-resistant strains were tested in this study.

All the organisms were maintained at $-20{ }^{\circ} \mathrm{C}$ in brain-heart infusion containing 20\% $(\mathrm{v} / \mathrm{v})$ glycerol. Before testing, the suspensions were transferred to nutrient broth and cultured overnight at $37^{\circ} \mathrm{C}$.
Twenty-six coagulase positive staphylococcus spp. and enterobacteria isolates from mastitis of cows, identified before were studied.

\section{Antimicrobial susceptibility test}

Globally, the antibiotic susceptibility test was carried out on 45 staphylococcal strains (10 S. aureus and $35 \mathrm{CNS}$ ) and 35 enterobacteria species isolated from milk samples which were collected from cases of mastitis in cow herds in Ain Defla province of Algeria during the years 2011-2013.

The antimicrobial susceptibility tests were performed according to CLSI M31-A3 agar diffusion method (Clinical and Laboratory Standards Institute, 2008) and included ceftiofur $(30 \mu \mathrm{g})$ (CEF), penicillin (10U) (PEN), ampicillin

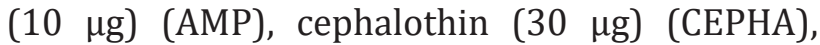
oxacillin (1 $\mu \mathrm{g})$ (OXA), erythromycin (15 $\mu \mathrm{g})$ (ERY) and tetracycline $(30 \mu \mathrm{g})$ (TET). Based on these tests, the isolates were divided into subgroups according to the resistance profiles.

The procedure followed is briefly described here. Enterobacteriaceae isolates were grown overnight on blood agar and colony suspension was prepared using the sterile saline water equivalent to a 0.5 -McFarland standard.

Suspension $(100 \mu \mathrm{l})$ was spread over the media plate and antibiotic disc was transferred aseptically on the surface of inoculated media plate. These plates were incubated after-ward at $35{ }^{\circ} \mathrm{C}$ for $24 \mathrm{~h}$.

Commercially available antimicrobial sensitivity discs (Oxoid) were used: Chloramphénicol (C) $(30 \mu \mathrm{g})$, Colistin (CS) $(50 \mu \mathrm{g})$, Amoxicillin + Clavulanic Acid (AMC) $(10 \mu \mathrm{g})$, Ampicillin (AMP) $(10 \mu \mathrm{g})$, Céfodiazin (CZ) $(30 \mu \mathrm{g})$, Amoxicillin (AM) $(30 \mu \mathrm{g})$, Ceftiofur (XNL) $(30 \mu \mathrm{g})$, Cefoxitin (FOX) $(30 \mu \mathrm{g})$, Cefotaxim (CTX) $(30 \mu \mathrm{g})$, Gentamicin (G)

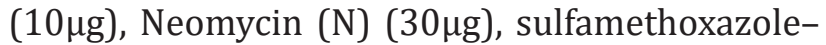
trimethoprim (SXT) $(25 \mu \mathrm{g})$, Tetracycline (TE) $(30 \mu \mathrm{g})$, Enrofloxacin (ENR) $(5 \mu \mathrm{g})$, Flumequin (FT) $(30 \mu \mathrm{g})$, Nalidixic Acid (NA) $(30 \mu \mathrm{g})$, Penicillin G(P) $(6 \mu \mathrm{g})$, Vancomycin (VA) $(30 \mu \mathrm{g})$, Clindamycin (CM)

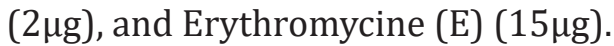

Quality controls were run using Escherichia coli ATCC 25922. S. aureus ATCC 25923 was used as control strain.

Cultures were classified as sensitive, intermediate and resistant on the basis of the inhibition zone diameter, according to the interpretive standards of Clinical Laboratory Standards Institute (CLSI, 2008). Isolates resistant to three 
or more antimicrobials were considered multiresistant (Waters et al., 2011).

After making the antimicrobial susceptibility tests, we have selected only multi drug resistant strains (number of 26).

\section{Plant materials and extract preparation}

Aerial parts of the medicinal plants Mentha pulegium, Lavendula dentate, Origanium sp, Marrubium vulgare, Salvia bicolor, Blackstonia perfoliata, and Phlomis crinita were freshly collected from different localities in Ain Defla (Algeria). The taxonomic identities of plants were confirmed by the botanical specialist from the agricultural department of Blida University (Algeria).

The plants were obtained by using their vernacular names and their botanical names were verified using a guide by Burkhill (1985).

\section{Preparation of plant extracts}

The plants were dried under shade in open air to reduce deterioration of the plant drug material. The collected plants were homogenized to a fine powder and stored in air-tight bottles at $4^{\circ} \mathrm{C}$.

The air-dried plant material was weighed and $250 \mathrm{~g}$ of each plant sample was extracted exhaustively and consecutively by using ethanol. The extracts were dried under reduced pressure at about $40^{\circ} \mathrm{C}$. Stock solutions of the extracts were prepared in dimethylsuphoxide (DMSO).

At the end of the extraction, each extract was filtered on filter paper. The filtrates obtained were evaporated.

\section{Antibacterial activity}

The extracts produced were tested against twenty six Staphylococci and enterobacteria strains isolated from animals with occurrence of mastitis cases reported in center region of Algeria. The isolates were previously grown in $3 \mathrm{~mL}$ of brain heart infusion broth (BHI) for $18 \mathrm{~h}$ at $37^{\circ} \mathrm{C}$ for the biological tests realization.

The antibacterial assay of aqueous and methanolic extracts was performed by agar disc diffusion method as described before (Harborne, 1973; Jamine et al, 2007).

In order to make the screening of antibacterial activity of the extracts, suspension of the bacteria containing $10^{6} \mathrm{UFC} / \mathrm{mL}$ was spread on Müeller Hinton agar and dried at room temperature. Filters paper disks impregnated with each plant extract stock solution were then placed on the plates, followed by $24 \mathrm{~h}$ of incubation at $37^{\circ} \mathrm{o}$. Distilled water and a standard antibiotic (gentamicin at concentration of $100 \mathrm{mg} / \mathrm{ml}$ ) were used as a positive control.

The antibacterial activity was calculated by measuring the inhibition zone diameter observed. So, after incubation, the inhibition zones were measured in millimeters. All the procedures have been approved by the Authors' Institution's Ethic Committee, and care was taken to comply with the 3R concept.

Statistical analysis was performed according to Student's t-test $(\mathrm{p}<0.05)$ in order to compare the results of the inhibition zones obtained from the methanolic extracts to the ones obtained from the positive control.

\section{Results and Discussion}

The paper describes the antimicrobial activity of a number of Algerian plants from Aindefla against several multiresistant Gram-positive and Gram-negative bacteria involved in bovine mastitis. The extracts of seven plant species were submitted in the screening.

The use of these plants in Algerian folk medicinal remedies for treating various health problems has already been reported by asked farmers. However, apart from Phyllanthus amarus, Piper aduncumand, Terminalia catappa, no scientific information concerning the antibacterial properties of these plants has been reported. No previous reports on the antibacterial activity of the other species could be found in literature (Tab 1).

Table 2 gives a summary of the investigated species, and the yield (\%) of methanolic extracts from the seventh plants. The maximum percentage yield was observed in polyphenolic extract from Blackstonia perfoliata followed by the polyphenol extract of Salvia bicolor with $28 \%$ and $17.7 \%$, respectively.

Table 3 indicates a total of seven medicinal plants that were collected from Aindefla State (Algeria). The botanical and vernacular names of the plant and the plant parts used together with their traditional therapeutic uses are presented. Methanolic extract from each of the plants were obtained and tested against Staphylococci and 
Table. 1. Plants used as antimicrobial in folk traditional medicine.

\begin{tabular}{|c|c|c|c|c|c|}
\hline $\begin{array}{l}\text { S. } \\
\text { No. }\end{array}$ & Plant name & Family & $\begin{array}{c}\text { Popular } \\
\text { names }\end{array}$ & Way of use & Indication and References \\
\hline 1 & Mentha pulegium & Lamiaceae & “Flio" & $\begin{array}{l}\text { Oral and } \\
\text { topic }\end{array}$ & $\begin{array}{l}\text { Farmers; Avancini et al., } \\
\text { 2008; Pramila et al., } 2012\end{array}$ \\
\hline 2 & Lavandula dentate & Lamiaceae & "Djaaida" & $\begin{array}{c}\text { Oral and } \\
\text { topic }\end{array}$ & Farmers; Data not published \\
\hline 3 & Origanium $s p$ & Filabiceae & “Zaater maaiz” & Oral & $\begin{array}{l}\text { Farmers; Baytop, 1999; } \\
\text { Molina et al., } 2010 \\
\end{array}$ \\
\hline 4 & Marrubium vulgare & Lamiaceae & “Marruouate" & Oral & Farmers; Data not published \\
\hline 5 & Salvia bicolor & Lamiaceae & $\begin{array}{l}\text { "Rokbate } \\
\text { ldjmal" }\end{array}$ & $\begin{array}{l}\text { Oral and } \\
\text { topic }\end{array}$ & $\begin{array}{l}\text { Farmers; Albuquerque et al., } \\
2007 \text {;Alvarenga et al., } 2007\end{array}$ \\
\hline 6 & $\begin{array}{l}\text { Blackstonia } \\
\text { perfoliata }\end{array}$ & Gentianaceae & "Elmarrara" & $\begin{array}{l}\text { Oral and } \\
\text { topic }\end{array}$ & Farmers; Data not published \\
\hline 7 & Phlomis crinita & Lamiaceae & $\begin{array}{l}\text { "Kayate } \\
\text { ladjrah" }\end{array}$ & & Farmers; Data not published \\
\hline
\end{tabular}

Table. 2. Extract yield of poly phenol of the investigated plants in this study.

\begin{tabular}{llccc}
\hline \multicolumn{1}{c}{ Plant species } & Extracts & $\begin{array}{c}\text { Plant parts } \\
\text { extracted }\end{array}$ & Weight (g) & Extract yield in \% \\
\hline Organium sp & Poly phenol & Leaf/Stem & 0,72 & 14,4 \\
\hline Salvia bicolor & Poly phenol & Stem & 0,88 & 17,6 \\
\hline Lavandula dentata & Poly phenol & Leaf & 0,71 & 14,2 \\
\hline Phlomis crinita & Poly phenol & Leaf/Stem & 0,17 & 3,4 \\
\hline Blackstonia perfoliata & Poly phenol & Leaf & 1,4 & 28 \\
\hline Mentha pelegium & Poly phenol & Leaf/Stem & 0,42 & 8,4 \\
\hline Marrubium vulgare & Poly phenol & Leaf/Stem & 0,52 & 10,4 \\
\hline
\end{tabular}

enterobacteria strains isolated from bovine mastitis.

Table 3 also indicates the results of the antimicrobial activities of the methanolic extract of each plant with respect to the test organism at concentration of $200 \mathrm{mg} / \mathrm{ml}$. A total of four plants did not show any activity. Antibacterial activity was found in three plant extracts where each extract inhibit one or more organisms. The antimicrobial activity of the extracts was directed mainly against the Gram-negative bacteria than Gram-positive bacteria. None of the extracts showed activity against SCP bacteria.

From Table 3, there are plants that are used to treat more than one ailment, for example,
Lavandula dentate used to treat headache and intestinal pain and Phlomis crinita for stomach pain, injury, abscess and as antiseptic. Table 3 also shows that various parts of a plant are used: the stem, the leaves or the whole plant.

The use of herbs as medicine is as old as humanity. For several reasons, people use plants for medication: improvement of health after herbal treatment, low cost of the drugs, non availability of synthetic drugs particularly in the rural areas of Aindefla State. The livestock owners in Algeria have been using traditional medication based on plant formulations since time immemorial. They utilize numerous plants and their various parts viz., roots, leaves, stems and rhizome for various 
Table 3. Botanical names, traditional uses of Algerian medicinal plants used in this study and their antimicrobial activity.

\begin{tabular}{|c|c|c|c|c|c|c|}
\hline \multirow{2}{*}{$\begin{array}{l}\text { Botanical name } \\
\text { (family) }\end{array}$} & \multirow{2}{*}{ House name } & \multirow{2}{*}{ Part used } & \multirow{2}{*}{$\begin{array}{c}\text { Claimed } \\
\text { medicinal uses }\end{array}$} & \multicolumn{3}{|c|}{ Antimicrobial activity } \\
\hline & & & & SCP & SCN & E.Coli \\
\hline $\begin{array}{l}\text { Mentha pulegium } \\
\text { (Filabiées) }\end{array}$ & Flio & $\begin{array}{l}\text { Leaves/ } \\
\text { Stem }\end{array}$ & $\begin{array}{l}\text { Fever, mouth and throat } \\
\text { Inflammation }\end{array}$ & - & - & - \\
\hline $\begin{array}{l}\text { Lavandula dentate } \\
\text { (Lamiaceae) }\end{array}$ & Djaaida & Leaves & $\begin{array}{c}\text { Headache } \\
\text { Intestinal pain }\end{array}$ & - & - & - \\
\hline $\begin{array}{l}\text { Origanium } s p \\
\text { (Filabiees) }\end{array}$ & Zaater maaiz & Leaves & Fever, grippe, diuretic & - & - & - \\
\hline $\begin{array}{l}\text { Marrubium vulgare } \\
\text { (Lamiaceae) }\end{array}$ & Marruouate & Whole plant & $\begin{array}{c}\text { Diarrhea, vermifuge, } \\
\text { Anthelmintics }\end{array}$ & - & + & - \\
\hline $\begin{array}{l}\text { Salvia bicolor } \\
\text { (Lamiaceae) }\end{array}$ & $\begin{array}{l}\text { Rokbate } \\
\text { ldjmal }\end{array}$ & Stem & $\begin{array}{c}\text { Kill lice, bruises } \\
\text { Emesis and nausea, } \\
\text { Wound } \\
\text { Fever, rheumatism }\end{array}$ & - & ++ & ++ \\
\hline $\begin{array}{l}\text { Blackstonia perfoliata } \\
\text { (Gentianaceae) }\end{array}$ & Elmarrara & Leaves & $\begin{array}{l}\text { Intestinal pain, } \\
\text { Gastric ulcers, } \\
\text { Anorexia }\end{array}$ & - & - & - \\
\hline $\begin{array}{l}\text { Phlomis crinita } \\
\text { (Lamiaceae) }\end{array}$ & $\begin{array}{l}\text { Kayate } \\
\text { ladjrah }\end{array}$ & Whole plant & $\begin{array}{c}\text { Stomach pain } \\
\text { Injury, abscess, } \\
\text { antiseptic, cicatrizing } \\
\text { on wounds }\end{array}$ & - & ++ & ++ \\
\hline
\end{tabular}

Note: $(-)$ : no inhibition; $(+)$ : weak inhibition $(<15 \mathrm{~mm}) ;(++)$ : strong inhibition $(>15 \mathrm{~mm})$; coagulase positive staphylococci $($ CPS $)$, coagulase positive staphylococci (SCN) and Escherichia coli.

ethno-veterinary practices. Herbal preparations are crude and could potentially be toxic. The antimicrobial activity of seven medicinal plants was evaluated in this work (Table 3). Antibacterial effect of extracts from seven plants by agar well diffusion method is shown in Table 4.

The maximum inhibition zone of CPS, SCN and Escherichia coli obtained by Phlomis crinita, $11 \mathrm{~mm}$, and by Salvia bicolor, $11 \mathrm{~mm}$ respectively. CPS, SCN and Escherichia coli are globally resistant to Mentha pulegium, Lavandula dentate, Origanium sp, Blackstonia perfoliata.

With exception of Blackstonia perfoliata, Lavendula dentate and Mentha pulegium, all others tested plants possessed antibacterial activity against at least one bacterial strain (CPS, SCN and Escherichia).

From seven plants, four showed antimicrobial properties (57.14\%), which confirm their popular use and justify the ethno-botanical approach in the search for novel biologically active compounds.
For all of them this is the first report of such activity. Among the medicinal plants tested in this work, Salvia bicolor and Phlomis crinita showed the most promising antibacterial properties, indicating the potential for discovery of antibacterial principles. We assume that some of the previously isolated compounds could be present in the extracts investigated and could partially contribute to antimicrobial activity reported in this study. However, further phytochemical studies are required to determine the types of compounds responsible for the antibacterial effects of these species.

The result of disk and well diffusion agar against these multi-drugs pathogens were confirmed each other. The size of inhibition zone was different according to the type of bacteria which is in accordance with the result obtained by Arab Soleimani et al. (2010).

The results obtained in the course of the present study are in agreement to a certain degree 
Table 4. Results of the antibacterial activity of ethno-veterinary medicinal plants by measuring of zone of inhibition (ZOI) in desk diffusion assay method.

\section{ZOI of phenolic extracts in $\mathrm{mm}$}

\begin{tabular}{cccccccc}
\hline Strains & $\begin{array}{c}\text { Salvia } \\
\text { bicolor }\end{array}$ & $\begin{array}{c}\text { Blackstonia } \\
\text { perfoliata }\end{array}$ & $\begin{array}{c}\text { Lavendula } \\
\text { dentata }\end{array}$ & $\begin{array}{c}\text { Mentha } \\
\text { pulegium }\end{array}$ & $\begin{array}{c}\text { Origanium } \\
\text { s }\end{array}$ & $\begin{array}{c}\text { Marrubium } \\
\text { vulgare }\end{array}$ & $\begin{array}{c}\text { Phlomis } \\
\text { crinita }\end{array}$ \\
\hline $\mathbf{0 1}$ & $\mathrm{R}$ & $\mathrm{R}$ & $\mathrm{R}$ & $\mathrm{R}$ & $\mathrm{R}$ & $\mathrm{R}$ & $\mathrm{R}$ \\
\hline $\mathbf{0 2}$ & $\mathrm{R}$ & $\mathrm{R}$ & $\mathrm{R}$ & $\mathrm{R}$ & $\mathrm{R}$ & $\mathrm{R}$ & 9 \\
\hline 03 & $\mathrm{R}$ & $\mathrm{R}$ & $\mathrm{R}$ & $\mathrm{R}$ & $\mathrm{R}$ & $\mathrm{R}$ & $\mathrm{R}$ \\
\hline 04 & $\mathrm{R}$ & $\mathrm{R}$ & $\mathrm{R}$ & $\mathrm{R}$ & $\mathrm{R}$ & $\mathrm{R}$ & $\mathrm{R}$ \\
\hline 05 & $\mathrm{R}$ & $\mathrm{R}$ & $\mathrm{R}$ & $\mathrm{R}$ & $\mathrm{R}$ & $\mathrm{R}$ & $\mathrm{R}$ \\
\hline 06 & $\mathrm{R}$ & $\mathrm{R}$ & $\mathrm{R}$ & $\mathrm{R}$ & $\mathrm{R}$ & $\mathrm{R}$ & $\mathrm{R}$ \\
\hline 07 & $\mathrm{R}$ & $\mathrm{R}$ & $\mathrm{R}$ & $\mathrm{R}$ & $\mathrm{R}$ & $\mathrm{R}$ & $\mathrm{R}$ \\
\hline 08 & $\mathrm{R}$ & $\mathrm{R}$ & $\mathrm{R}$ & $\mathrm{R}$ & $\mathrm{R}$ & $\mathrm{R}$ & $\mathrm{R}$ \\
\hline 09 & $\mathrm{R}$ & $\mathrm{R}$ & $\mathrm{R}$ & $\mathrm{R}$ & $\mathrm{R}$ & $\mathrm{R}$ & 7 \\
\hline 10 & $\mathrm{10}$ & $\mathrm{R}$ & $\mathrm{R}$ & $\mathrm{R}$ & $\mathrm{R}$ & $\mathrm{R}$ & 9 \\
\hline 11 & $\mathrm{R}$ & $\mathrm{R}$ & $\mathrm{R}$ & $\mathrm{R}$ & 6 & $\mathrm{R}$ & $\mathrm{R}$ \\
\hline 12 & $\mathrm{R}$ & $\mathrm{R}$ & $\mathrm{R}$ & $\mathrm{R}$ & $\mathrm{R}$ & $\mathrm{R}$ & $\mathrm{R}$ \\
\hline 13 & $\mathrm{R}$ & $\mathrm{R}$ & $\mathrm{R}$ & $\mathrm{R}$ & $\mathrm{R}$ & $\mathrm{R}$ & $\mathrm{R}$ \\
\hline 14 & $\mathrm{R}$ & $\mathrm{R}$ & $\mathrm{R}$ & $\mathrm{R}$ & $\mathrm{R}$ & $\mathrm{R}$ & $\mathrm{R}$ \\
\hline 15 & $\mathrm{R}$ & $\mathrm{R}$ & $\mathrm{R}$ & $\mathrm{R}$ & $\mathrm{R}$ & $\mathrm{R}$ & $\mathrm{R}$ \\
\hline 16 & $\mathrm{11}$ & $\mathrm{R}$ & $\mathrm{R}$ & $\mathrm{R}$ & $\mathrm{R}$ & 8 & $\mathrm{R}$ \\
\hline $\mathbf{1 7}$ & $\mathrm{R}$ & $\mathrm{R}$ & $\mathrm{R}$ & $\mathrm{R}$ & 1 & $\mathrm{R}$ & $\mathrm{R}$ \\
\hline 18 & $\mathrm{10}$ & $\mathrm{R}$ & $\mathrm{R}$ & $\mathrm{R}$ & $\mathrm{R}$ & $\mathrm{R}$ & $\mathrm{R}$ \\
\hline 19 & $\mathrm{R}$ & $\mathrm{R}$ & $\mathrm{R}$ & $\mathrm{R}$ & $\mathrm{R}$ & $\mathrm{R}$ & $\mathrm{R}$ \\
\hline 20 & $\mathrm{R}$ & $\mathrm{R}$ & $\mathrm{R}$ & $\mathrm{R}$ & $\mathrm{R}$ & $\mathrm{R}$ & $\mathrm{R}$ \\
\hline 21 & $\mathrm{R}$ & $\mathrm{R}$ & $\mathrm{R}$ & $\mathrm{R}$ & $\mathrm{R}$ & $\mathrm{R}$ & $\mathrm{R}$ \\
\hline 22 & $\mathrm{R}$ & $\mathrm{R}$ & $\mathrm{R}$ & $\mathrm{R}$ & $\mathrm{R}$ & $\mathrm{R}$ & $\mathrm{R}$ \\
\hline 23 & $\mathrm{R}$ & $\mathrm{R}$ & $\mathrm{R}$ & $\mathrm{R}$ & 1 & $\mathrm{R}$ & $\mathrm{R}$ \\
\hline 24 & $\mathrm{R}$ & $\mathrm{R}$ & $\mathrm{R}$ & $\mathrm{R}$ & $\mathrm{R}$ & $\mathrm{R}$ & 11 \\
\hline 25 & $\mathrm{R}$ & $\mathrm{R}$ & $\mathrm{R}$ & $\mathrm{R}$ & $\mathrm{R}$ & $\mathrm{R}$ & $\mathrm{R}$ \\
\hline 26 & $\mathrm{R}$ & $\mathrm{R}$ & $\mathrm{R}$ & $\mathrm{R}$ & $\mathrm{R}$ & $\mathrm{R}$ & $\mathrm{R}$ \\
\hline
\end{tabular}

Note: R: resistant.

with the traditional use of the plants evaluated. Two of them have been used by local farmers in mastitis treatment while the others were chosen due to previous reports. Among the plant extracts produced, three inhibited the growth of evaluated strains. The antibacterial activity correlated with some of the claims of the traditional uses of the plants. Some of the plants appear to have broad spectrum of action.

The results showed that methanolic extract of these plants could inhibit the growth of strains isolated from bovine mastitis. Salvia bicolor and Phlomis crinite extracts showed the strongest antistaphylococcal activity, followed by extract of the Marrubium vulgare which displayed moderate activity.

Indeed, the local population uses the local flora in various medicinal uses. The high pressure herds sheep, cattle and goats takes the squandering of plant cover. These plants are palatable and are sought in the grazing herds (Latreche and Mehdadi, 2013).

However, the extracts produced contain not only one but a mixture of compounds among a single one or a few responsible for the biological 
activity, what makes necessary the identification of the most relevant substances in later studies.

Although the plants differ significantly in their activities against the tested bacteria, more of the extracts showed antimicrobial activity against SCN and E.coli than against SCP.

From this study we can conclude that the plants Phlomis crinata and Salvia bicolor possessed the highest antimicrobial activity. All these species are seasonal herbs widely used as medicines but not described before in the Algeria.

Medicinal plant can be poisonous if wrong plant parts or wrong concentrations are used (Frohne, 1999). The hepatotoxic potential of conventional drugs is well known while herbal medicines are often assumed to be harmless.

Besides the traditional use of Origanum species as a spicy additive for food, the genus has several applications in folk medicine as sedative, diuretic, degasifier, sweater and antiseptic, and also in the treatment of gastrointestinal diseases and constipation (Baytop, 1999).

Some of these plant species seem to be valuable sources for antibacterial drugs against bacteria, especially against multiresistant microorganisms.

The bioassay-guided fractionation procedure to characterize and isolate the antibacterial active constituents is under way in our laboratory. In addition, these plants are currently being investigated for other pharmacological activities.

The result of the antimicrobial activity of the plant extracts is particularly important considering these multidrug organisms, which they inhibited. The extracts of these plants contain substances that are true antibacterials. Isolation of the active constituents of those plants that indicate broad spectrum of activity is in progress.

\section{Conclusion}

Algerian flora is a part of the Mediterranean botanical richness, large hot spot of the global plant diversity. Many of the plants used by farmers in Algeria have popular indication of antibacterial activity. Our results, although, revealed only the potential of the extracts obtained from Salvia bicolor, Marrubium vulgare and Phlomis crinita against strains of bovine mastitis origin. Among the two plants indicated by the farmers for the treatment of mastitis, Phlomis crinita was the only one that validated the popular use of medicinal plants in the management of this disease. Our results validate the use in Algerian culture of some plants that can be easily found in our flora and some worldwide. The results support the possible use of these in the clinical management of this disease as phytotherapic agent but, research is therefore needed to determine optimal doses and concentrations of the preparations and to identify the side effects of the remedies. Moreover, the efficacy of the preparations, techniques, and practices need to be investigated to identify promising plants for use in livestock development proposals. Further studies may be necessary to elucidate the specific phytoactive compounds and hence to go for commercial application through pharmaceutical industries.

Conflict of interest statement. We declare that we have no conflict of interest.

Acknowledgements. We would like to thank to Gouzi hichem, Faculty of sciences, department of biology, Laghouat University, Laghouat, Algeria.

\section{References}

1. Albuquerque UP, Monteiro JM, Ramos MA, Amorim ELC (2007). Medicinal and magic plants from a public market in northeastern Brazil. Journal of Ethnopharmacology, 110: 76-91.

2. Al-Judaibi E (2014). Infection and Antibiotic Resistant Bacteria in Developing Countries: A Genetic Review. Journal of Microbiology Research, 4(6A): 10-17. http:// dx..doi.org/10.5923/s.microbiology.

3. Alvarenga AL, Schwan RF, Dias DR, Schwan-Estrada KRF, Bravo-Martins CEC (2007). Atividade antimicrobiana de extratos vegetais sobre bactérias patogênicas humanas. Rev Bras Plant Med, 9: 86-91.

4. Arab SN, Kermanshahi RK, Yakhchali B, Sattari TN (2010). Antagonistic activity of Probiotic lactobacilli against Staphylococcus aureus isolated from bovin mastitis. African Journal of Microbiology Research, 4: 2169- 2173.

5. Avancini C, José MW, Rodrigo DALL'AGNOL, Juliana SH \& Gilsane LVP (2008). Antimicrobial Activity of Plants Used in the Prevention and Control of Bovine Mastitis in Southern Brazil. Latin American Journal of Pharmacy. Lat Am J Pharm, 27(6): 894-9.

6. Baytop $\mathrm{T}$ (1999). Therapy with Medicinal Plants in Turkey: Today and in Future. Istanbul University Press, Istanbul, Turkey, 166-167.

7. Bradley AJ, Leach KA, Breen JE, Green LA, Green MJ (2004). Survey of the incidence and etiology of mastitis on dairy farms in England and Wales. Veterinary Record, 160: 253-257.

8. Burkhill HM (1985). The Useful Plants of West Tropical Africa. Second ed., vol. I. Royal Botanic Gardens, Kew, pp. 1-6.

9. Clinical and Laboratory Standards Institute (2008). Performance standards for antimicrobial disk and dilution 
susceptibility tests for bacteria isolated from animals: approved standard. $3^{\text {rd }}$ ed. Wayne: CLSI, $112 \mathrm{p}$.

10. Frohne D (1999). Plant intoxicants - is there a risk from herbal preparation? Z. Phytoterapie, 20: 201-202, 205208.

11. Harborne JB (1973). Phytochemical methods. London Chapman and Hall, Ltd, pp. 49-88.

12. Hebert A, Sayasith K, Senechal S, Dubreuil P, Lagace J (2000). Demonstration of intracellular Staphylococcus aureusin bovine mastitis alveolar cells and macrophages isolated from naturally infected cow milk. Microbiol Lett, 193: 57-62.

13. Jasmine R, Daisy P, Selvekumar BN (2007). In vitro efficacy of flavonoids from Eugenia jambolana seeds against ESAYL-producing multidrug-resistant enteric bacteria. Research Journal of Microbiology, 2(4): 369-374.

14. Latreche A, Mehdadi Z (2013). Study of local rarityof Phlomis crinita Cav. (Lamiaceae) in the mountains of Tessala (Western Algeria). $3^{\text {rd }}$ International Conference on Advances in Biotechnology and Pharmaceutical Sciences (ICABPS'2013), January 8-9, Kuala Lumpur (Malaysia). p17.

15. Molina AC, González MA, Viturro CI (2010). Antiradical and cytotoxic activity of Origanum species extracts. Molecular Medicinal Chemistry, 21, 60-63.

16. Pandian MR, Banu GS, Kumar G (2006). A study of antimicrobial activity of Alangium salviifolium. Indian Journal of Pharmacology, 38: 203-204.

17. Pramila DM, Xavier R, Marimuthu K, Kathiresan S, Khoo ML, Senthilkumar M, Sathya K, Sreeramanan S (2012).
Phytochemical analysis and antimicrobial potential of methanolic leaf extract of peppermint (Mentha piperita: Lamiaceae). Journal of Medicinal Plants Research, 6(2): 331-33. http://dx.doi.org/10.5897/JMPR11.1232.

18. Principe P (1989). The Economic Significance of Plants and their Constituents as Drugs, in. Wagner H, Hikino $\mathrm{H}$ and Farnsworth N. Economic and Medicinal Plant Research, 3: 1-17. London: Academic Press, London, Great Britain.

19. Saidi R, Khelef D, Kaidi R (2013). Subclinical mastitis in cattle in Algeria: Frequency of occurrence and bacteriological isolates. Journal of the South African Veterinary Association, 84(1), Doi: http://dx.doi. org/10.4102/jsava.v84i1.929

20. Sivananthan M (2013). Antibacterial activity of 50 medicinal plants used in folk Medicine. International Journal of Biosciences, 3(4): 104-121. Doi: http://dx.doi. org/10.12692/ijb/3.4.104-121

21. Tamert A (2012). Salvia et Phlomis of Tessala montains (Western Algeria). Histology, ecology and valorisation. Mem. Magister univ. Djilali Liabes, 112p.

22. Waters A, Contente-Cuomo T, Buchhagen J, Liu C, Watson L, Pearce K, Foster J, Bowers J, Driebe E, En-gelthaler D, Keim P, Price L (2011). Multidrug-resistant Staphylococcus aureus in US meat and poultry. Clinical Infectious Disease, 52: 1227-1230.

23. Zeraïa L (1983). Protection de la flore. Liste et localisation des espèces assez rares, rares et rarissimes. Station Centrale de Recherche en Ecologie Forestière. Alger, Algérie. 